Rok XVI (2021) | 2 (32) | S. 47-59

https://doi.org/10.12797/LV.16.2021.32.05

Ewa Młynarczyk ๑

Uniwersytet Pedagogiczny im. Komisji Edukacji Narodowej, Kraków

ewa.mlynarczyk@up.krakow.pl

\title{
FRAZEMATYCZNY POTENCJAŁ POŁĄCZENIA WYRAZOWEGO BIEDA Z NĘDZA WE WSPÓŁCZESNEJ POLSZCZYŹNIE
}

Słowa klucze: frazematyka, przysłowia, wartościowanie, intertekstualność Keywords: phrasematics, proverbs, evaluation, intertextuality

\section{Wstęp}

Bolesne doświadczenia związane z brakiem środków materialnych koniecznych do zaspokojenia podstawowych potrzeb życiowych to jedna $\mathrm{z}$ dziedzin życia odzwierciedlonych w zasobach leksykalnych i frazeologicznych polszczyzny (por. Gumowska 2014, 2016; Młynarczyk 2015). Wiele jednostek jedno- i wielowyrazowych prymarnie nazywających różne aspekty trudnej sytuacji materialnej z czasem zyskało dodatkowe znaczenia, dzięki czemu odnoszą się również do innych realiów i sfer życia. Tak stało się w przypadku dwóch leksemów nazywających trudne położenie materialne: bieda i nędza. 


\section{Komponenty}

Rzeczownik bieda ${ }^{1}$ we współczesnej polszczyźnie ogólnej ${ }^{2}$ występuje w znaczeniach: 'brak wystarczających środków materialnych do zaspokajania potrzeb życiowych', 'trudna, przykra sytuacja; nieszczęście, kłopot', a także 'ogół ludzi niezamożnych; biedacy, nędzarze', realizujące metonimiczny model 'cecha, właściwość' > 'osoby noszące tę cechę' (por. SWJP: 57; WSJP PAN). W zbiorach leksykograficznych umieszcza się także informację, iż w polszczyźnie potocznej rzeczownik bieda wymawiany jest często ze wzmacniającym ekspresję ścieśnieniem samogłoski: bida ${ }^{3}$ (WSJP PAN; PSWP IV: 229; SWJP: $57^{4}$ ), np. Ale bida! Jaka tam bida!. W takich i podobnych kontekstach leksem ten jest używany z silnym nacechowaniem ekspresywnym, charakterystycznym dla większości wyrazów spokrewnionych z wyrazem bieda, jak biedak, biedny, biedaczka, biedactwo itp., które mogą odnosić się neutralnie do osób w trudnym położeniu materialnym albo do istot (osób, zwierząt), którym mówiący chce okazać współczucie, litość lub pobłażanie czy lekceważenie (por. hasło biedny w DSS: 21-22).

Synonimem gradacyjnym biedy jest rzeczownik nędza, który w polszczyźnie funkcjonuje w prymarnym znaczeniu 'bardzo trudna sytuacja materialna'; $\mathrm{w}$ definicjach słownikowych podkreśla się jego intensyfikujący charakter: 'bieda w stopniu najwyższym, brak podstawowych środków do życia; wielkie ubóstwo, niedostatek' (SJPD IV: 1313), 'skrajne ubóstwo, wielka bieda, niedostatek' (SWJP: 584) [podkr. E.M.]. Różnice gradacyjne między oboma synonimami są eksponowane w niektórych kontekstach, np. Cała młodość borykat sie już nie z biedą, ale z nędza (SJPD IV: 1313). Metonimicznie rzeczownik nędza, podobnie jak bieda, może nazywać osoby: 'ludzie pozbawieni podstawowych środków do życia' (WSJP PAN).

Wyraz ten jest też określeniem negatywnie wartościującym, co znajduje odzwierciedlenie w słownikowych definicjach i zamieszczonych w nich egzemplifikacjach tekstowych: 'coś bardzo marnego, lichego, w podłym gatunku, tandeta', np. Ta książka to zupetna nędza (SWJP: 584); 'używane jako negatywne określenie czegoś, co się mówiącemu nie podoba', np. Cały ten festiwal to nędza, podobnie jak Opole (WSJP PAN); 'bezwartościowość wynikająca z ujemnych cech', np. Lada dzień kolorowe liście zakryją, choć w części, brud, nędzę i brzydotę świata wokót nas (ibid.). Aksjologiczny aspekt przejawia się szczególnie w łączliwości rzeczownika nędza z wyrazami

1 Etymologia i rozwój formalno-znaczeniowy wyrazu bieda por. Gumowska-Grochot (2020).

2 Sporo znaczeń leksemu bieda jest poświadczonych wyłącznie w gwarach. Całościowo strukturę semantyczną rzeczownika bieda/biada omawia Ilona Gumowska-Grochot (ibid.).

3 W cytowanych poniżej egzemplifikacjach tekstowych leksem bieda jest zapisywany dwojako: bieda i bida. W postaciach inwariantnych przyjmuję postać bieda.

4 W SWJP (s. 57) zamieszczono odrębne hasło bida $\mathrm{z}$ kwalifikatorami reg. pot. i z definicją ' $\mathrm{z}$ dystansem, niechęcią o czyjejś biedzie, nędzy’. 
nazywającymi różne cechy charakteru i postępowania człowieka: nędza duchowa, moralna, nędza egzystencji, życia (ibid.).

Oba synonimiczne wyrazy, bieda i nędza, prymarnie oznaczają zatem trudną sytuację materialną, ale różnią się gradacją, intensywnością nazywanego zjawiska i częściowo konotacjami przejawiającymi się w znaczeniach przenośnych i w derywatach - z bieda związane są konotacje 'współczucia, litości, stanu godnego pożałowania', mogące też towarzyszyć niektórym użyciom wyrazu nędza (por. obraz nędzy i rozpaczy 'o kimś lub o czymś znajdującym się w bardzo złym stanie, stanowiącym widok wzbudzający litość; SFzP: 299), ale przeważają jednak inne 'lichy wygląd, zła jakość, niska wartość.

\section{Bieda z nędzq}

Upostaciowione pojęcia biedy i nędzy występują w bajkach ludowych ${ }^{5}$. SWil jako definicje kolejnych znaczeń wyrazów podaje charakterystykę postaci mitologicznych:

Bieda (zn. 3) mit. słowiańsko-pogańska boginka piekielna, w służbie Rugewita, a siostra i towarzyszka Nędzy. Jest wybladła, żółta, ma żupan dziurawy, kawałkiem niegdyś bogatego pasa przepasany, czapkę podartą i obówie (!) dziurawe. Wiele jest o dwu tych istotach pięknych powieści ludowych, ob. Nędza (SWil I: 76).

Nędza (zn. 5) mit. słowiańsko-pogańska boginka piekielna w służbie Rugiewita, a towarzyszka Biedy. Nędza z Biedą dwie przyjaciółki i siostry, w piekle narodzone, a po ziemi chodzące, nawiedzają marnotrawców i rozrzutników. Do kogo się przyczepią, ten zawżdy sam temu winien, gdyż bogowie, co do szczęścia stworzyli ludzi, karzą złych nieszczęściem. O nędzy i Biedzie, jako dwu niewiastach, krąży u ludu dość powieści, ob. Bieda (ibid.: 155).

Autorzy SWil podkreślają, że pojęcia te (a zatem też ich nazwy) występują wspólnie w „powieściach ludowych”. W SW (I: 147) jako znaczenie 3. rzeczownika bieda podano 'postać nadprzyrodzona uosabiająca niedolę, a pod nim połączenie wyrazowe Bieda $z$ Nędzą oraz zdanie - Bieda śpi razem $z$ Nędzą. Definicja znaczeniowa i zapis rzeczowników od wielkich liter wskazują, że są to przykłady egzemplifikujące raczej ludowe wyobrażenia, a nie utrwalony frazem o przenośnym znaczeniu. Dokumentują one jednak kojarzenie obu pojęć i współwystępowanie w tekście nazywających je leksemów.

Wyobrażenie Biedy utożsamianej z Nędzą opisują autorzy Encyklopedii demonów na podstawie źródeł etnograficznych:

5 Najpopularniejszym motywem bajkowym jest uwięzienie Biedy przez ubogiego chłopa w jakimś przedmiocie, na przykład w kości, dzięki czemu tenże chłop znacznie się wzbogaca. Bogacz, powodowany zazdrością, uwalnia Biedę, która zaczyna mieszkać u niego (Krzyżanowski 1962: 114). 
Bieda, bieda, Bida, bida - nieśmiertelna istota demoniczna przedstawiana w postaci chudej kobiety, będącej uosobieniem plagi rodu ludzkiego, polegającej na zgryzotach, cierpieniach psychicznych, troskach. Wysysająca z człowieka krew, czyli siły witalne, zwykle utożsamiana z Nędzą (Podgórscy 2000: 34).

Pod hasłem Nędza znajduje się podobny opis (ibid.: 265).

Łączenie obu pojęć i nazywających je rzeczowników według Juliana Krzyżanowskiego (1958: 315) związane jest z utrwalonym w ludowym świecie przekonaniem o sile zjawisk negatywnych przejawiającej się między innymi w ich multiplikacji. Przekonanie to utrwalają liczne przysłowia rejestrowane w NKPP (I: 94-101), np. Jedna bieda to nie bieda; Nie uczyni jedna bieda nic, aż sie ich kilka musi zbiec; Bieda nędzę pogania; Pobrała się bieda z nędza (zob. też Młynarczyk 2016).

Personifikacja pojęć kojarzonych z ciężkim położeniem materialnym jest mocno utrwalona w polskiej frazeologii i paremiologii ${ }^{6}$, a także w różnych tekstach kultury. Już w XVII w. (przed 1633 r.) ukazała się anonimowa satyra Nędza z Bieda $z$ Polski ida (Badecki 1950: 221-242), która zyskała dużą popularność i była wielokrotnie wznawiana w całym XVII i w XVIII w.

Okładka ówczesnych wydań książki przedstawia tytułowe pojęcia - dwie półnagie postaci uosabiające ludowe wyobrażenia niedostatku materialnego, obie w łachmanach, Nędza z siecią na grzbiecie, a Bieda z koszem, w którym dźwiga czworo dzieci (ibid.). Obie idą z wyniszczonej Polski do dalekich Włoch (Krzyżanowski 1958: 315). Satyra ta, mająca postać dialogu, w którym uczestniczą tytułowe postaci, była wielokrotnie inscenizowana, między innymi w formie słuchowiska w Polskim Radiu w 1974 r. Uosabiane pojęcia występują także w tekście Kazimierza Wójcickiego Nędza z Biedą. Baśń ludowa (Wójcicki 1881).

Ludowe wyobrażenia oraz oparte na nich teksty kultury stanowią prawdopodobnie płaszczyznę źródłową frazemów ${ }^{7}$, w których podstawowym elementem kompozycyjnym jest połączenie synonimicznych leksemów za pomocą przyimka $z$ : bieda $z$ nędzq lub (rzadziej) w odwrotnym szyku nędza z bieda.

W NKPP (I: 95) pod hasłem bieda $z$ nędza jako najstarszą egzemplifikację zamieszczono tytuł wspomnianej wyżej XVII-wiecznej satyry. Pozostałe cytaty są dokumentacją krótszych i dłuższych jednostek wielowyrazowych z dwojakim szykiem omawianego połączenia wyrazów: Bieda z nędza; Nędza z bieda; Nędza z biéda w párze chodza; Nędza $z$ bieda $w$ parze idą; Bieda $z$ bieda $w$ parze ida; Biéda z nędza okoma jida, oraz z dodatkowym członem: Nędza z bieda $w$ taniec ida, a mizeria gra (mizeria 'bieda').

6 Antropomorfizacja to jeden $\mathrm{z}$ wyrazistych składników obrazu biedy utrwalonego $\mathrm{w}$ gwarach i w tekstach ludowych (Rak 2015: 242; Gumowska 2016), a także w polszczyźnie ogólnej (Młynarczyk 2015), np. bieda zaglada komu w oczy, bieda przychodzi do kogo, bieda czai się na kogo itp.

7 Terminem frazem posługuję się w rozumieniu Wojciecha Chlebdy, który tym mianem obejmuje wszystkie jednostki wielowyrazowe odtwarzalne „w danej sytuacji pragmatycznej” bez względu na ich status formalny i stopień nieregularności semantycznej (Chlebda 1993: 328) 
Celem niniejszego artykułu jest ustalenie, $w$ jakich wariantach i znaczeniach funkcjonują we współczesnej polszczyźnie frazemy oparte na połączeniu bieda $z$ nę$d z a$ / nędza $z$ biedą. Materiał został zebrany z dostępnych w Internecie tekstów, co dało możliwość ekscerpcji bardzo zróżnicowanych tematycznie, gatunkowo i stylistycznie wypowiedzi - informacji medialnych, nagłówków, tytułów publikacji, blogów, wpisów na forach internetowych. Dobór tak rozmaitych tekstów miał na celu sprawdzenie, jakie jednostki wielowyrazowe mają rzeczywiste poświadczenie w polszczyźnie XXI w. - cytowane przykłady pochodzą z lat 2000-2021.

Frazem w najkrótszej postaci został udokumentowany zarówno w różnych tekstach, jak i w zbiorach leksykograficznych. SJPD (IV: 1314) podaje pod hasłem nędza dwie definicje: bieda $z$ nędzq 'wielka bieda, wyjątkowa bieda, nędza', 'biedni ludzie, nędzarze, biedacy; rzadziej: biedny człowiek, nędzarz’ W słownikach z przełomu XX i XXI w. frazem jest rejestrowany $\mathrm{z}$ kwalifikatorem potoczny w postaciach bieda $z$ nędzq i bida $z$ nędza, w NKJP udokumentowana jest także postać z odwróconym szykiem: nędza $z$ bidą. Definicje znaczeń w słownikach dotyczą sfery materialnej: 'skrajne ubóstwo' (SWJP: 57), 'o beznadziejnej sytuacji materialnej, braku wszystkiego' (SFzP: 16) lub, bardziej ogólnie, 'bardzo zła sytuacja, zwłaszcza materialna’ (WSJP PAN). Efekt hiperbolizacji zjawiska jest wzmocniony połączeniem dwóch synonimicznych wyrazów, z których jeden ma intensyfikujący charakter.

W Słowniku polszczyzny potocznej (SPP: 261) podano definicję (z kwalifikatorem lekceważąco) 'coś marnego, złego, bezwartościowego' z egzemplifikacją tekstową: A to twoje ostatnie wypracowanie, to już naprawdę bida $z$ nędzą.

Wśród przykładów ekscerpowanych z różnorodnych tekstów część dokumentuje użycie omawianego frazemu w znaczeniu 'skrajne ubóstwo', np.:

Kiedy byłyśmy małe - opowiadała kiedyś ciocia Jasia - była taka bieda z nędzą, że na nas trzy była jedna para butów, bo ze starych już wyrosłyśmy, i w tej jednej parze butów chodziliśmy na zmianę (NKJP, 2007).

W Lipianach wkopali się w długi. „Bida z nędzą i stagnacja” (gs24.pl) ${ }^{8}$.

Byłam w Grecji i bida z nędzą aż piszczy (f.kafeteria.pl).

Inne cytaty odnoszą się do różnych aspektów sfery materialnej - do sytuacji ekonomicznej czy spraw bankowych, np. Podkarpacka „bida $z$ nędzq" (super nowosci24.pl) ${ }^{10}$; Bida $z$ nędza [nagłówek artykułu na temat sytuacji na rynku lokat

8 Spis źródeł internetowych znajduje się na końcu artykułu.

9 Wzmocnienie przekazu uzyskano tu poprzez kontaminację frazemu bida z nędzą z innym, bieda aż piszczy.

10 Występujący w wielu przykładach cudzysłów jest sygnałem frazematyczności lub/i stylowego dysonansu - potoczności frazemu w oficjalnym tekście. W niektórych przykładach jest znakiem przytoczenia. 
bankowych] (comperia.pl); Nasza strefa to „bida i nędza” [o strefie ekonomicznej] (olsztyn.wyborcza.pl).

Znaczna część poświadczeń tekstowych omawianego frazemu dotyczy jednak różnorodnych zjawisk i wydarzeń niepowiązanych z sytuacją materialną:

Bida z Nędzą, czyli pucharowe granie w Kuźni Raciborskiej (sport.nowiny.pl).

Powiem tak: bida z nędzą [o meczu piłki nożnej] (salon24.pl1).

Tańcowała bieda z nędzą - tak można określić to, co robi opozycja (telewizjarepublika.pl).

Bida z nędzą. Brak konkretnych informacji. Brak chęci pomocy i utrudnione uzyskiwanie informacji. Żenada (ubezpieczenie.com.pl).

W cytowanych przykładach frazem bieda $z$ nędza został użyty jako wielowyrazowa jednostka negatywnie wartościująca, w odniesieniu do sytuacji, przedmiotów, wydarzeń, które w opinii mówiącego cechuje jakiś rodzaj niedostatku (na przykład informacji) lub zła jakość działań. Na tak formułowaną ocenę mają wpływ konotacje 'niewystarczająca ilość czegoś, zła jakość' związane z prymarnym znaczeniem frazemu 'skrajna bieda', charakterystyczne również dla samego rzeczownika nędza.

W tekstach współczesnej polszczyzny udokumentowane jest także znaczenie osobowe (kolektywne), np.: Na Mauritius nie wpuszczaja czarterowych samolotów. Bida $z$ nędza niech sobie lata na Majorkę (KJP PWN).

Część przykładów wskazuje, że frazem bida $z$ nędza jest umieszczany również w zupełnie nowych kontekstach interpretacyjnych, które przywołują innego rodzaju konotacje związane $\mathrm{z}$ niedostatkiem materialnym, raczej pozytywne: 'prostota, zwyczajność, brak ozdobników'. Są one wykorzystywane w przekazach marketingowych, na przykład na jednym z blogów kulinarnych: Jeszcze jedna wersja „bidy z nędza" - makaron z ziemniakami; Risotto z ziemniakami, czyli bida $z$ nędza (kuchniawkamiennymdomu.blogspot.com). Nazwy potraw nawiązują do skojarzeń z ubogim, bardzo skromnym, niewyszukanym pożywieniem, zjadaniem resztek jedzenia, nie zawsze pasujących do siebie. Konotacje prostoty są uaktualniane także w innych nazwach, na przykład podpłomyków nędza, zachwalanych na jednym $\mathrm{z}$ blogów wpisem o tytule $\mathrm{w}$ formie przekształconego frazemu: Nędza, ale bez bidy.

Do stereotypowych wyobrażeń sposobu ubierania się osób mających trudną sytuację materialną odwołuje się natomiast autorka bloga, która zrobiony przez siebie sweterek nazwała bida $z$ nędza (to też tytuł wpisu), prezentując go następująco: „Prosty, gładki, szary [...] Wygląda trochę jak ta bida ostatnia [...] Tak, że ten. Bida z nędzą przez wieś pędzą" (sivka-malaszafa.blogspot.com). Konotacje prostoty i zwyczajności łączą się tu zarówno z ubóstwem, jak i z szarością, ukazanymi przewrotnie (i autoironicznie) jako pozytywne cechy opisywanych wyrobów. 
Jeszcze inny rodzaj konotacji związanych $\mathrm{z}$ biedą jest wykorzystywany w zoonimii i chrematonimii. Bieda i Nędzq - jak czytamy w zapisach blogowych - zostały nazwane psy i koty (podpis pod zdjęciem: Bida $z$ Nędzq - moje ulubione koty) (krakvet.pl). Motywację nadania imion psom wyjaśnia komentarz: „Zjawiły się razem i ktoś krzyknął: Jaka bieda z nędzą! I tak zostało" (szczecinek.com). Na wybór nazw istotny wpływ miały zatem konotacje 'litość, współczucie, czułość' charakterystyczne dla rzeczownika bieda i aktualizowane zwłaszcza w odniesieniu do istot małych, drobnych, wymagających opieki.

Potoczny, powszechnie znany frazem jest także wykorzystywany w firmonimii jako element swoistej gry językowo-kulturowej służącej celom marketingowym. Bida $z$ Nędza to nazwa kilku pensjonatów oraz dwóch ośrodków wczasowych w Polsce, z których jeden nosi nazwę Bida, drugi - Nędza, reklamowane są zaś wspólnie jako Bida $z$ Nędza (bidaznedza.pl). Wykorzystanie frazemu o negatywnych konotacjach w przekazie reklamującym obiekty o wysokim standardzie jest formą językowego i kulturowego żartu, który świadczy jednocześnie o dużej rozpoznawalności i ekspresywności tego połączenia wyrazowego.

Omawiana jednostka wielowyrazowa jest wykorzystywana także w tekstach artystycznych. Utwór Tańcowały bida z nędzą Andrzeja Nowickiego to żartobliwy tekst z uosobionymi postaciami Biedy i Nędzy, które upijają się i na jeden dzień dają światu od siebie odpocząć (tekstowo.pl1). Bida $z$ nędzą Piotra Bukartyka to twórcze przekształcenie frazemów, szczególnie w refrenie:

Idą, idą, lecą, pędzą nędza z bidą i bida z nędzą

Idą, idą, idą, idą nędza z bidą

Idą, idą, lecą, pędzą nędza z bidą i bida $\mathrm{z}$ nędzą

Idą, idą, idą, idą nędza z bidą (tekstowo.pl2).

Cała piosenka jest rodzajem artystycznego komentarza dotyczącego materialnej sfery życia, zwłaszcza w powiązaniu z różnicami w hierarchii społecznej.

\section{Nędza z biedq̨ z Polski idq}

W zebranym materiale została również poświadczona postać frazemu tożsama z tytułem wspomnianej wyżej XVII-wiecznej satyry - z rymowaną klamrą tworzoną przez wyrażenie w szyku nędza z biedą i orzeczenie czasownikowe idą. Postać taka jest wykorzystywana między innymi w ideonimach, które są zapewne świadomymi nawiązaniami do znanego utworu, na przykład w tytule spektaklu muzycznego Nędza $z$ Bieda $w$ Polskę idą (mumerus.net), w którym zastosowano innowację wymieniającą (przyimki), co powoduje zmianę znaczenia całej frazy. Inny rodzaj transformacji (innowację rozwijającą) zastosowano natomiast w tytule spektaklu prezentowanego przez teatr kukiełkowy: Nędza z Bidą z Polski precz idą (e-teatr.pl). 
Wymiana członów nierymowanych następuje nie tylko w tekstach artystycznych, ale też w innych - w tytułach prac naukowych, na przykład artykułu Nędza z bida $w$ parze ida. O sytuacji nauczycieli w XIX wieku (marzenabogus.pl) oraz tekstu Nędza $z$ bida zewszad ida poświęconego projektowi badań ubóstwa w miastach europejskich, między innymi w Łodzi (sprawynauki.edu.pl).

Twórcze wykorzystanie omawianej frazy znajdziemy również we współczesnych mediach, na przykład w nagłówkach prasowych: Nędza z bida w Polskę idq - o ubóstwie w polskich rodzinach (tygodnikprzeglad.pl); Nędza $z$ bidq $z$ Polski ida, ale $z$ Polski nie wynida - o koronawirusie (passa.waw.pl) i w komentarzach internetowych, na przykład: Nędza $z$ bida $w$ Polskę ida? - o wpuszczaniu na polski rynek tańszych towarów gorszej jakości (marucha.wordpress.com).

\section{Bida z nędzq̨ przez wieś pędzq}

W tekstach współczesnej polszczyzny poświadczona została także fraza dłuższa, w której rymowaną klamrę stanowi wyrażenie bida $z$ nędzą i orzeczenie czasownikowe $p e ̨ d z a$, a wymianie podlega komponent środkowy, nierymowany. W zebranym materiale najczęściej występuje postać Bida z nędza przez wieś pędza, np. Jacyków o strojach gwiazd na Telekamerach: Bida z nędza przez wieś pędzą (plotek.pl); Bida $z$ nędza przez wieś pędzą. Widzę że w waszej gminie coraz większa padaka [komentarz do konkursu robótek ręcznych zorganizowanego na terenie gminy] (zgorze lec.info).

W podobnych kontekstach zostały udokumentowane inne warianty: Bieda $z$ nedza przez świat pędzą. No i dotarly do Polski (7dni.wordpress.com); Bida z nędza przez kraj pędza [wpis w sprawie produktu krajowego brutto] (pl.pregierz.narkive. com). Fraza ta bywa też doraźnie aktualizowana za pomocą członów odnoszących się do poruszanego tematu: Bida $z$ nędza bimber pędzą ${ }^{11}$ (scigacz.pl); Bida $z$ nędzą przez Polskę pędza (salon24.pl2); Bida $z$ nędza przez las pędzą (nagrzyby.pl); Bida $z$ nędza we dwie pędza (KJP PWN).

Struktura semantyczna omawianej frazy jest podobna jak w krótszej postaci (bida $z$ nędza). Niektóre z przykładów egzemplifikują znaczenie 'bardzo trudne położenie materialne, widoczne oznaki biedy', np. Bida $z$ nędzą przez życie pędzą [o dzieciach z biednych rodzin] (bezkomentarza.pl); Kenia - dzień 5 - Bida z nędza przez kraj pędza [o trudnych warunkach bytowych w podróży] (makoweabc.pl). Inne cytaty odnoszą się do różnych aspektów sytuacji materialnej, jednak przeważająca część poświadcza używanie tej frazy w funkcji określenia wartościującego w odniesieniu

11 W tym przypadku wykorzystano dwuznaczność czasownika pędzić 'przemieszczać się bardzo szybko w określonym kierunku', 'produkować domowym sposobem napój alkoholowy' (WSJP PAN). 
do różnych elementów rzeczywistości, które w opinii mówiącego zostały wykonane z ubóstwem środków, prymitywnie, bez polotu, w sposób dający efekt śmieszności lub wstydu.

\section{Podsumowanie}

Połączenie wyrazowe, którego źródeł można upatrywać w demonologii ludowej i współwystępujących tam upostaciowionych pojęciach Biedy i Nędzy, stało się osią konstrukcyjną kilku frazemów udokumentowanych we współczesnej polszczyźnie krótszych: bieda z nędza; nędza z bieda oraz dłuższych: Nędza $z$ bieda z Polski ida; Bieda $z$ nędza przez wieś/kraj/świat pędza (we wszystkich postaciach rzeczownik bieda może występować w wariancie fonetycznym bida). W większości zbiorów leksykograficznych rejestrowany jest krótszy wariant (bieda $z$ nędza), w PSWP (XXIII: 226) zamieszczono także wariant Nędza $z$ bieda $w$ parze idą. W słownikach polszczyzny ogólnej zdefiniowano znaczenia związane z sytuacją materialną, ciężkim położeniem, jedynie w SPP podano znaczenie z nacechowaniem aksjologicznym. Element semantyczny wychodzący poza kwestie związane z sytuacją materialną został uwzględniony w definicji zawartej w WSJP PAN 'bardzo zła sytuacja, zwłaszcza materialna' [podkr. - E.M.], ale cytaty zamieszczone przy haśle nie dokumentują tego rozszerzenia, odnoszą się do kwestii ekonomicznych.

Analiza zebranego materiału wykazała, że w znaczeniu prymarnym omawiane frazemy służą wyrażaniu oceny dotyczącej sytuacji materialnej lub ekonomicznej osób, małych i większych społeczności bądź instytucji. Frazy te są jednak częściej używane jako jednostki negatywnie wartościujące w odniesieniu do różnych sfer rzeczywistości, wykorzystuje się je do wyrażania opinii na temat zjawisk i wydarzeń, które w ocenie mówiących charakteryzują się niską jakością, mają widoczne braki i niedociągnięcia wynikające nie tyle $z$ trudności materialnych, ile raczej z zaniedbań czy ze złego gustu. Dłuższa fraza ma przy tym silniejszą moc illokucyjną, zwłaszcza z komponentem wieś, kojarzonym z derywatami wsiok i wieśniak (zn. 2), zdefiniowanymi w WSJP PAN jako 'człowiek prymitywny i nieumiejący się zachować, z kwalifikatorami potocznie, pejoratywnie.

Wszystkie wymienione frazemy podlegają modyfikacjom w tekstach, co świadczy o istnieniu inwariantów utrwalonych w świadomości użytkowników języka. Ustabilizowanie omawianych jednostek dokumentowane jest przez różnorodność egzemplifikujących je cytatów, zazwyczaj pochodzących z tekstów reprezentujących potoczną odmianę polszczyzny (wypowiedzi na forach internetowych) lub posługujących się nią celowo (nagłówki prasowe, teksty artystyczne i marketingowe, chrematonimy) dla ekspresywnego wzmocnienia przekazu i zabiegów intertekstualnych. Niektóre użycia są oparte na pozytywnych konotacjach 'współczucia, czułości' (w zoonimii) lub 'prostoty, zwyczajności' (w marketingu). 
Omówione frazemy to świadectwo potencjału językowego i kulturowego potocznych jednostek wielowyrazowych, atrakcyjnych dla użytkowników języka ze względu na wyraziste nacechowanie ekspresywne i aksjologiczne. Świadectwa tej atrakcyjności i żywotności frazemów, a także ich wariantów, występują w jak najszerzej rozumianych tekstach współczesnej kultury.

\section{Źródła internetowe}

bezkomentarza.pl: https://bezkomentarza.wordpress.com/2014/o7/3o/bida-z-nedza-przezzycie-pedza-ludzie-bezdomni/ (dostęp: 9 VII 2021).

bidaznedza.pl: http://bidaznedza.pl/zieleniec/?page=kontakt (dostęp: 2 XII 2020).

comperia.pl: https://www.comperia.pl/1884-bida-z-nedza (dostęp: 2 II 2021).

e-teatr.pl: https://e-teatr.pl/krakow-premiera-i-przeglad-przedstawien-teatru-mumerus-a5 6370 (dostęp: 1 II 2021).

f.kafeteria.pl: https://f.kafeteria.pl/temat/f1/bylam-w-grecji-i-bida-z-nedza-az-piszczy-p_68 20204 (dostęp: 4 II 2020).

gs24.pl: https://gs24.pl/w-lipianach-wkopali-sie-w-dlugi-bida-z-nedza-i-stagnacja/ar/54424 o6 (dostęp: 4 II 2020).

krakvet.pl: https://www.krakvet.pl/forum/koty-pozostale-sprawy-f16/bida-z-nedza-mojeulubione-koty-t11330 (dostęp: 2 XII 2017).

kuchniawkamiennymdomu.blogspot.com: http://kuchniawkamiennymdomu.blogspot.com/ 2018/o8/jeszcze-jedna-wersja-bidy-z-nedza.html (dostęp: 2 II 2021).

makoweabc.pl: http://www.makoweabc.pl/2012/12/kenya-dzien-5-bida-z-nedza-przez-krajpedza/ (dostęp: 9 II 2021).

marucha.wordpress.com: https://marucha.wordpress.com/2017/o1/29/nedza-z-bida-w-pol ske-ida/ (dostęp: 4 II 2021).

marzenabogus.pl: http://marzenabogus.pl/2019/o6/o8/nedza-z-bida-w-parze-ida-o-sytuacji -nauczycieli-w-xix-wieku/ (dostęp: 4 II 2021).

mumerus.net: http://www.mumerus.net/external/mit_jarmark_pl.html (dostęp: 2 II 2021). nagrzyby.pl: https://nagrzyby.pl/relacje/bida-z-nedza-przez-las-pedza (dostęp: 9 II 2021).

olsztyn.wyborcza.pl: http://olsztyn.wyborcza.pl/olsztyn/1,48726,4150499.html (dostęp: 2 II 2021).

passa.waw.pl: https://www.passa.waw.pl/artykul/nedza-z-bida-z-polski-ida-ale-z-polski-nie -wynida, 4927 (dostęp: 4 II 2021).

plotek.pl: https://www.plotek.pl/plotek/1,78649,7507311,jacykow-o-strojach-gwiazd-na-tele kamerach-bida-z-nedza-przez.html (dostęp: 9 XII 2021).

pl.pregierz.narkive.com: https://pl.pregierz.narkive.com/1tN6lgsW/bida-z-n-dz-przez-krajp-dz (dostęp: 9 II 2021).

salon24.pl1: https://www.salon24.pl/u/empe/118941,powiem-tak-bida-z-nedza (dostęp: 4 II 2020).

salon24.pl2: https://www.salon24.pl/u/stopklatka/634008,bieda-z-nedza-przez-polske-pedza (dostęp: 9 II 2021).

scigacz.pl: www.scigacz.pl/Wniosek,jest,jeden,bida,z,nedza,bimber,pedza,komentarz,153331, 29162,cs.html (dostęp: 9 II 2021). 
sivka-malaszafa.blogspot.com: https://sivka-malaszafa.blogspot.com/2017/o2/bida-z-nedza. html (dostęp: 2 XII 2017).

sport.nowiny.pl:https://sport.nowiny.pl/120379-bida-z-nedza-czyli-pucharowe-granie-w-ku zni-raciborskiej-zdjecia.html (dostęp: 2 II 2021).

sprawynauki.edu.pl: http://www.sprawynauki.edu.pl/archiwum/dzialy-wyd-papierowe/14nauki-spoleczne/69-54 (dostęp: 4 II 2021).

supernowosci24.pl: http://supernowosci24.pl/podkarpacka-\%E2\%80\%9Cbida-Z-nedza\%E2\% 80\%9D/ (dostęp: 2 II 2021).

szczecinek.com: szczecinek.com/artykul/bieda-i-nedza-bieda/220993 (dostęp: 2 II 2017).

tekstowo.pl: https://www.tekstowo.pl/piosenka,ewa_dalkowska,tancowaly_bida_z_nedza. html (dostęp: 11 III 2021).

tekstowo.pl2: https://www.tekstowo.pl/piosenka,piotr_bukartyk,bida_z_nedza.html (dostęp: 9 II 2021).

telewizjarepublika.pl: https://telewizjarepublika.pl/czarnecki-tancowala-bieda-z-nedza-takmozna-okreslic-to-co-robi-opozycja,70641.html (dostęp: 4 II 2020).

tygodnikprzeglad.pl: https://www.tygodnikprzeglad.pl/nedza-bieda-polske-ida/ (dostęp: 4 II 2021).

ubezpieczenie.com.pl: https://www.ubezpieczenie.com.pl/forum/opinie-o-towarzystwachubezpieczen/allianz/bida-z-nedza-wojtek-61344 (dostęp: 2 II 2021).

zgorzelec.info: https://www.zgorzelec.info/\#!/news/6357 (dostęp: 9 II 2021).

7dni.wordpress.com: https://7dni.wordpress.com/2009/03/13/bieda-z-nedza-przez-swiatpedza/ (dostęp: 9 II 2021).

\section{Literatura}

BADECKi K., 1950, Polska satyra mieszczańska. Nowiny sowiźrzalskie, Kraków.

Chlebda W., 1993, Frazematyka, [w:] J. Bartmiński (red.), Encyklopedia kultury polskiej XX wieku, t. 2: Współczesny język polski, Wrocław, s. 327-334.

DSS: A. Nagórko, M. Łaziński, H. Burkhardt, Dystynktywny słownik synonimów, Kraków 2004.

GumowsKa I., 2014, Językowy obraz biedy w „Łomżyńskich tekstach gwarowych”, [w:] H. Sędziak, D. Czyż (red.), Polszczyzna Mazowsza i Podlasia, t. 18: Językowa przeszłość i współczesność Mazowsza i Podlasia, Łomża, s. 173-184.

GumowsKa I., 2016, Językowy obraz biedy w związkach frazeologicznych i paremiach o charakterze gwarowym, [w:] M. Rak, K. Sikora (red.), Słowiańska frazeologia gwarowa, „Biblioteka LingVariów", t. 23, Kraków, s. 267-277.

GumowsкA-Grochot I., 2020, Polska BIEDA w perspektywie etymologicznej, historycznojęzykowej i dialektologicznej, „Etnolingwistyka. Problemy Języka i Kultury” 32, s. 51-65, https://doi.org/10.17951/et.2020.32.51.

KJP PWN: Korpus Języka Polskiego PWN, [on-line:] https://sjp.pwn.pl/korpus.

KRZYŻanowsKi J., 1958, Mądrej głowie dość dwie słowie, t. 1: Trzy centurie przysłów polskich, Warszawa.

KrzyżANOWski J., 1962, Polska bajka ludowa $w$ układzie systematycznym, t. 1, wyd. 2 rozszerz., Warszawa. 
MŁynarczyk E., 2015, Polski obraz biedy utrwalony w języku i kulturze, „Etnolingwistyka. Problemy Języka i Kultury” 27, s. 147-165, https://doi.org/10.17951/et.2015.27.147.

MŁYNARCZYK E., 2016, Zwielokrotnienie zjawisk jako składnik językowego obrazu świata w polskich przysłowiach na temat biedy, „Studia Slavica” XX/1, s. 77-84.

Narodowy Korpus Języka Polskiego, praca zbiorowa, red. A. Przepiórkowski, M. Bańko, R.L. Górski, B. Lewandowska-Tomaszczyk, Warszawa 2012.

NKJP: Narodowy Korpus Języka Polskiego, [on-line:] nkjp.pl.

NKPP: J. Krzyżanowski (red.), Nowa księga przysłów i wyrażeń przysłowiowych polskich, t. 1-4, Warszawa 1969-1978.

Podgórscy B. i A., 2000, Encyklopedia demonów. Diabły, diabełki, jędze, skrzaty, boginki... i wiele innych, Wrocław.

PSWP: H. Zgółkowa (red.), Praktyczny słownik współczesnej polszczyzny, t. 1-50, Poznań 1994-2005.

RAK M., 2015, Kulturemy podhalańskie, „Biblioteka LingVariów”, t. 19, Kraków, https://doi. org/10.12797/9788376386027.

SFzP: A. Kłosińska, E. Sobol, A. Stankiewicz (oprac.), Wielki słownik frazeologiczny PWN z przysłowiami, Warszawa 2005.

SJPD: W. Doroszewski (red.), Słownik języka polskiego, t. I-XI, Warszawa 1958-1969.

SPP: J. Anusiewicz, J. Skawiński, Słownik polszczyzny potocznej, Warszawa - Wrocław 1996.

SW: J. Karłowicz, A.A. Kryński, W. Niedźwiedzki (red.), Słownik języka polskiego, t. I-VIII, Warszawa 1900-1927.

SWIL: A. Zdanowicz i in. (red.), Słownik języka polskiego, t. I-II, Wilno 1861, [on-line:] eswil. ijp.pan.pl.

SWJP: B. Dunaj (red.), Słownik współczesnego języka polskiego, Warszawa 1996.

Wielki słownik języka polskiego PAN. Geneza, koncepcja, zasady opracowania, P. Żmigrodzki, M. Bańko, B. Batko-Tokarz, J. Bobrowski, A. Czelakowska, M. Grochowski, R. Przybylska, J. Waniakowa, K. Węgrzynek, Kraków 2018.

WójCicki K.W., 1881, Nędza z Biedą. Baśń ludowa (baśnie i podania ludu polskiego), Warszawa.

WSJP PAN: P. Żmigrodzki (red.), Wielki słownik języka polskiego PAN, [on-line:] wsjp.pl.

\section{Phrasematic Potential of the Word Combination: bieda z nędzq in Contemporary Polish Abstract}

The combination of synonymous words, whose origin may be associated with folk demonology and personified notions of Bieda [Poverty] and Nędza [Misery], has become the basis for a few phrasemes that are authenticated in contemporary Polish language.

The analysis of research material that includes a variety of texts, differing in terms of topic, genre and style, is the evidence that apart from the phraseme bieda $z$ nędza, which is registered in dictionaries, also other multi-verbal units, whose basic element of composition is this particular word combination, are used in Polish. The primary significance of the analysed phrasemes results from the presence of two synonymous words denoting a difficult financial situation, which leads to the hyperbolisation of the phenomenon. From the pragmatic perspective, however, they are used mostly as negative evaluation units, referring to the material sphere, but also to various fields, phenomena and events, which, according to the speaker, are characterised by low quality, have visible shortages and 
symptoms of poverty, or result from negligence or bad taste. As expressively and axiologically marked terms, which are characteristic of the colloquial style, these phrasemes are encountered in comments and discussion forums, as well as media coverage, especially in headlines. Longer phrasemes, which are joined by a clear rhyme, are the elements of intertextual games in various cultural texts: artistic works, blogs and chrematonyms. 